\title{
Erratum to: Over-incarceration and disenfranchisement
}

\author{
Murat C. Mungan ${ }^{1}$
}

\section{Erratum to: Public Choice \\ DOI 10.1007/s11127-017-0448-6}

The publisher regrets that due to an unfortunate turn of events in Eqs. (32) and (34) erroneous mathematical expression was introduced during article processing. Both equations have been corrected in the article and should be regarded as the final version by the reader.

The original article was corrected.

The online version of the original article can be found under doi:10.1007/s11127-017-0448-6.

$\triangle$ Murat C. Mungan

mmungan@gmu.edu

1 Antonin Scalia Law School at George Mason University, Arlington, VA, USA 